\title{
STUDI PENAMBAHAN AIR ADONAN TERHADAP KARAKTERISTIK STIK PANGSIT
}

\author{
Saripudin, S.TP ${ }^{(1)}$ dan Hermiza Mardesci, S.TP., MP ${ }^{(2)}$ \\ (1) Alumni Teknologi Pangan Faperta UNISI \\ ${ }^{(2)}$ Dosen Teknologi Pangan Faperta UNISI \\ mimzaaci@yahoo.co.id
}

\begin{abstract}
Abstrak
Penelitian ini bertujuan untuk mengetahui pengaruh penambahan air adonan yang tepat terhadap karakteristik stik pangsit. Rancangan percobaan penelitian ini adalah menggunakan Rancangan Acak Lengkap (RAL) dengan empat perlakuan penambahan air adonan $(\mathrm{A}=30 \%$ air yang ditambahkan, $\mathrm{B}=35 \%$ air yang ditambahkan, $\mathrm{C}=40 \%$ air yang ditambahkan, $\mathrm{D}=45 \%$ air yang ditambahkan. Analisa dilakukan untuk menentukan kadar air, kadar pati, dan organoleptik (warna, aroma, rasa dan tekstur). Untuk hasil terbaik dari hasil penelitian penambahan air adonan adalah pada perlakuan A (30\% air yang ditambahkan) yaitu dengan kadar air $1,2761 \%$, kadar pati $48,708 \%$, uji organoleptik warna $4,2500 \%$, aroma $3,7500 \%$, rasa $3,6500 \%$, dan tekstur 4,0500\%. Penambahan air adonan sebanyak 30\% yaitu sebanyak $150 \mathrm{ml}$ air memiliki jumlah kadar air terendah dan sesuai dengan standar mutu makanan ringan ekstrudat dimana jumlah kadar air maksimal $4 \%$.
\end{abstract}

Kata kunci : Stik pangsit, kadar air, air adonan

\section{PENDAHULUAN}

Makanan ringan adalah makanan yang bukan merupakan menu utama yang dimaksudkan untuk menghilangkan rasa lapar seseorang sementara waktu dan dapat memberi sedikit suplai energi ke tubuh atau merupakan sesuatu yang dimakan untuk dinikmati rasanya (Putri, 2011). Produk yang termasuk dalam kategori makanan ringan menurut Surat Keputusan Kepala BPOM Republik Indonesia tanggal 9 Oktober 2006 tentang Kategori Pangan adalah semua makanan ringan yang berbahan dasar kentang, umbi, serealia, tepung atau pati dalam bentuk krupuk, kripik, jipang dan produk ekstrusi seperti chiki-chiki-an. Salah satu jenis makanan ringan yang sering dijumpai di warung-warung atau swalayan di kota Tembilahan adalah stik pangsit.
Stik pangsit merupakan jenis makan ringan yang berbahan dasar tepung terigu dan dengan bahan tambahan lainnya yaitu air, garam, ragi, bumbu dan tepung tapioka. Salah satu faktor yang menentukan karakteristik stik pangsit yang baik adalah penambahan jumlah air adonan yang tepat. Permasalahan yang menjadi dasar dilakukan penelitian ini adalah jumlah air adonan yang tepat untuk pengolahan stik pangsit, maka penulis telah melakukan penelitian dengan judul "Studi Penambahan Air Adonan terhadap Karakteristik Stik Pangsit".

\section{Tujuan Penelitian}

1. Untuk mengetahui pengaruh penambahan air adonan terhadap karakteristik stik pangsit.

2. Untuk mengetahui hasil perlakuan terbaik dari pengaruh 
penambahan air adonan terhadap karakteristik stik pangsit. (kadar air, kadar pati, dan uji organoleptik).

\section{Manfaat Penelitian}

1. Hasil yang akan diperoleh dari penelitian ini diharapkan dapat menentukan jumlah penambahan air adonan yang tepat pada pembuatan stik pangsit sehingga menghasilkan stik pangsit dengan karakteristik yang baik.

2. Memberikan informasi kepada masyarakat tentang penambahan air adonan yang tepat terhadap karakteristik stik pangsit yang tepat pada pembuatan stik pangsit.

\section{METODE PENELITIAN}

\section{Bahan}

Bahan yang digunakan dalam penelitian ini adalah tepung terigu, tepung tapioka, air, garam, telur, ragi, bumbu dan minyak goreng. Bahan analisa yang digunakan yaitu HCL $3 \%$, $\mathrm{NaOH} 10 \%$, larutan Luff-Schoorl, aquades, asam sulfat $6 \mathrm{~N}$, natrium tiosulfat $0,1 \mathrm{~N}$, kalium iodide, kanji $0,5 \%$, alumuniaum foil.

\section{Alat}

Alat yang digunakan di dalam penelitian ini adalah Kompor, baskom, kuali, alat pencetak (Ampia), sendok kuali, penyaringan, erlenmeyer, desikator, timbangan analitik, oven.

\section{Metode Penelitian}

Rancangan percobaan yang digunakan di dalam penelitian ini adalah Rancangan Acak Lengkap (RAL) terdiri dari empat perlakuan yaitu :

$\mathrm{A}=30 \%$ air yang ditambahkan

$\mathrm{B}=35 \%$ air yang ditambahkan
$\mathrm{C}=40 \%$ air yang ditambahkan

$\mathrm{D}=45 \%$ air yang ditambahkan

Perlakuan ini diulang sebanyak 3 kali sehingga diperoleh pula perlakuan 4 x 3 dengan jumlah 12 perlakuan. Model rancangan yang digunakan adalah sebagai berikut :

$\mathrm{Y} i \mathrm{ij}=\mu+\mathrm{Pi}+\mathrm{Eij}$

di mana :

Yij = hasil pengamatan terhadap jumlah air adonan (1-4) dalam pembuatan stik pangsit dengan ulangan (1-3)

$\mu=$ Nilai rata-rata

$\mathrm{Pi}=$ Pengaruh jumlah air adonan (1-4) pada ulangan (1-3)

$\mathrm{E}=$ pengaruh sisa pada satuan percobaan yang mendapatkan perlakuan jumlah air adonan (1-4) pada ulangan (13)

I = Perlakuan jumlah air adonan (1-3)

$\mathrm{J}=$ Ulangan (1-3)

Hasil data dianalisa secara statistik, jika $\mathrm{F}$ hitung > dari $\mathrm{F}$ tabel, maka dilakukan uji lanjut dengan menggunakan Uji Beda Nyata Jujur (BJN). taraf nyata $5 \%$.

\section{Pelaksanaan Penelitian}

Proses Pembuatan Mie (Zuhry, 2010) yang Telah Dimodifikasi Oleh Penulis

1. Persiapan bahan baku

Tepung yang digunakan adalah tepung terigu berprotein sedang merek segitiga biru dan tepung tapioka. Tepung terigu dan tepung tapioka yang digunakan sebaiknya yang bewarna putih bersih, tidak berkutu dan bebas dari benda asing. Air yang digunakan air hangat dengan suhu $50{ }^{\circ} \mathrm{C}$, bersih dan tidak berbau.

2. Pencampuran

Tepung terigu ditimbang 500 gram, tepung tapioka 250 gram, garam 10 gram, ragi 5 gram dan telur 1 butir. Diaduk sampai rata. Kemudian 
tambahkan air sedikit demi sedikit dengan perlakuan (30\% air, 35\% air, $40 \%$ air, dan $45 \%$ air) sambil aduk hingga adonan dapat dibentuk.

3. Pengadonan

Adonan diaduk sampai kalis. Pengadonan berfungsi untuk mencampur secara homogen semua bahan, mendapatkan hidrasi yang sempurna pada karbohidrat dan protein, membentuk dan melunakkan glutein hingga tercapai adonan yang kalis. Tanda-tanda adonan telah kalis adalah jika adonan tidak lagi menempel di wadah atau di tangan atau saat adonan dilebarkan (Mudjajanti dan Yulianti, 2004).

4. Pembentukan Lembaran

Pembentukan lembaran bertujuan untuk menghaluskan serat-serat gluten dan membuat lembaran adonan. Adonan yang dipress sebaiknya tidak bersuhu rendah yaitu kurang dari $25^{\circ} \mathrm{C}$, karena pada suhu tersebut menyebabkan lembaran adonan pecah-pecah dan kasar. Mutu lembaran adonan yang demikian akan menghasilkan stik pangsit yang mudah patah. Tebal akhir adonan sekitar $3 \mathrm{~mm}$.

5. Pencetakan Lembaran

Pencetakkan di akhir proses pembentukan lembaran, lembar adonan yang telah ditentukan ketebalannya dipotong atau dicetak menggunakan alat pencetak atau ampia dengan panjang $6 \mathrm{~cm}$.

6. Penggorengan

Setelah pencetakan selesai dilakukan penggorengan pada suhu minyak goreng $120^{\circ} \mathrm{C}$ selama 15 menit atau warna stik pangsit menjadi kuning kecoklatan, kemudian diangkat dan didinginkan (Suprapto, 2004).

\section{HASIL DAN PEMBAHASAN}

\section{Kadar Air}

Kadar air merupakan banyaknya air yang terkandung dalam bahan yang dinyatakan dalam persen. Rata-rata hasil studi penambahan air adonan terhadap karakteristik stik pangsit terhadap kadar air yang dihasilkan dapat dilihat pada Tabel 1.

Tabel 1.Hasil Studi Penambahan Air Adonan terhadap Kadar Air pada Stik Pangsit yang Dihasilkan

\begin{tabular}{|l|c|}
\hline \multicolumn{1}{|c|}{ Perlakuan } & Rata-rata (\%) \\
\hline $\mathrm{B}=35 \%$ air yang ditambahkan & $2.1520 \mathrm{a}$ \\
\hline $\mathrm{D}=45 \%$ air yang ditambahkan & $1.8034 \mathrm{ab}$ \\
\hline $\mathrm{C}=40 \%$ air yang ditambahkan & $1.7449 \mathrm{ab}$ \\
\hline $\mathrm{A}=30 \%$ air yang ditambahkan & $1.2761 \mathrm{~b}$ \\
\hline
\end{tabular}

Keterangan : Angka-angka pada jalur atau kolom yang sama diikuti oleh huruf kecil yang sama berbeda nyata menurut uji lanjut (BJN) pada taraf nyata $5 \%$.

Hasil analisa sidik ragam dari perlakuan studi penambahan air adonan terhadap karakteristik stik pangsit berbeda nyata pada taraf 5\% menurut uji lanjut BNJ terhadap parameter kadar air. Jumlah kadar air tertinggi terdapat pada perlakuan B (35\% air yang ditambahkan) yaitu sebesar $2.1520 \%$ dan jumlah kadar air terendah pada perlakuan A $(30 \%$ air yang ditambahkan) yaitu sebesar $1.2761 \%$. Jumlah kadar air yang ada pada stik pangsit yang diberi $35 \%$ air yang ditambahkan pada adonan yang dihasilkan memiliki jumlah kadar air yang tinggi. Hal tersebut disebabkan karena penambahan jumlah air 
merupakan faktor utama dalam membuat adonan yang baik, air merupakan komponen penting dalam bahan makanan, air dapat mempengaruhi penampilan, tekstur, serta cita rasa makanan. Air juga merupakan bahan baku yang menentukan konsistensi dan karakteristik reologi adonan selama proses pembuatan stik pangsit.

Menurut Astawan (1999), tepung terigu memiliki kemampuan untuk membentuk gluten pada saat terigu dibasahi dengan air. Gluten yang tinggi mengakibatkan daya ikat air pada stik pangsit menjadi tinggi, hal ini disebabkan pembentukan gluten terjadi karena pencampuran tepung terigu dengan air pada saat proses mixing(pengulenan).

Pada proses pembentukan adonan stik pangsit air yang ditambahkan sebanyak $35 \%$ yaitu $175 \mathrm{ml}$ air. Sedangkan pada jumlah kadar air terendah terdapat pada perlakuan A (30\% air). Hal ini disebabkan pada proses pembuatan adonan stik pangsit air yang ditambahkan yaitu sebanyak 150 $\mathrm{ml}$ sehingga pembentukan adonan agak sulit untuk dibentuk dan susah untuk dicetak. Berdasarkan SNI 01-2886-2000 (2000), Syarat mutu makanan ringan ekstrudat dengan persyaratan kadar air yaitu maksimal. $4 \%$.

Daya serap air pada tepung terigu adalah berapa banyak kita dapat menambahkan / memasukkan air ke dalam adonan. Semakin tinggi protein terigu semakin tinggi pula daya serap airnya. Jumlah air yang ditambahkan pada umumnya sekitar 28\%-38\% dari campuran bahan yang akan digunakan. Jika lebih dari $38 \%$ adonan akan menjadi sangat lengket dan jika kurang dari $28 \%$ adonan akan menjadi sangat rapuh sehingga sulit dicetak (Widyaningsih dan Murtini, 2006).

Penggunaan air yang terlalu banyak akan mengakibatkan adonan menjadi lengket dan sulit ditangani, sedangkan jika terlalu sedikit akan mengakibatkan produk akhir akan menjadi keras. Air yang digunakan adalah air yang layak dikonsumsi. Kandungan mineral dalam air juga berpengaruh terhadap adonan. Air lunak seperti destilat atau air hujan akan menyebabkan adonan menjadi lengket dan kurang mengembang karena air ini tidak mengandung mineral yang dapat meningkatkan kekuatan (Sapta, 2011).

\section{Kadar Pati}

Pati memainkan peranan penting pada pengembangan produk pangan, baik sebagai bahan baku atau bahan tambahan seperti pengental, penstabil, atau penguat tekstur. Penambahan pati ditujukan untuk meningkatkan retensi air, mengontrol mobilitas air, dan juga menjaga kualitas produk pangan selama penyimpanan (Pongsawatmanit, et al., 2001).

Rata-rata hasil studi penambahan air adonan terhadap karakteristik stik pangsit terhadap kadar pati yang dihasilkan dapat dilihat pada Tabel 2.

Tabel 2.Hasil Studi Penambahan Air Adonan terhadap Kadar Pati pada Stik Pangsit terhadap Kadar Pati Stik Pangsit yang Dihasilkan

\begin{tabular}{|l|c|}
\hline \multicolumn{1}{|c|}{ Perlakuan } & Rata-rata (\%) \\
\hline $\mathrm{D}=45 \%$ air yang ditambahkan & 51.612 \\
\hline $\mathrm{B}=35 \%$ air yang ditambahkan & 51.418 \\
\hline $\mathrm{A}=30 \%$ air yang ditambahkan & 48.708 \\
\hline $\mathrm{C}=40 \%$ air yang ditambahkan & 48.530 \\
\hline
\end{tabular}


Tabel 2 menunjukkan kadar pati tertinggi terdapat pada perlakuan D (45\% air yang ditambahkan) yaitu sebesar $51.612 \%$ dan jumlah kadar pati terendah pada perlakuan C $(40 \%$ air yang ditambahkan) yaitu sebesar $48.530 \%$. Jumlah kadar pati yang ada pada stik pangsit yang diberi $45 \%$ air yang ditambahkan pada adonan yang dihasilkan memiliki jumlah kadar pati yang tinggi. Hal tersebut disebabkan proses penambahan air sebanyak $200 \mathrm{ml}$ pada adonan, lebih banyak dari pada perlakuan lainnya, air masuk kedalam granula pati maka semakin banyak pati yang larut dalam air karena proses pemanasan, adonan tepung akan menyebabkan granula semakin membengkak karena penyerapan air semakin banyak. Pati akan membentuk sistem dispersi pati dengan air, karena pati mengandung amilosa dan amilopektin yang memiliki gugus hidroksil yang reduktif. Gugus hidroksil akan bereaksi dengan hidrogen dari air. Kemampuan menyerap air yang besar pada pati diakibatkan karena molekul pati mempunyai jumlah gugus hidroksil yang sangat besar (Winarno, 2002). Menurut Muchtadi et al. (1988), amilopektin dapat merangsang terjadinya proses mekar (puff) sehingga produk dengan kadar amilopektin tinggi bersifat ringan, porus, garing dan gampang patah (renyah). Pati yang mengandung amilosa tinggi cenderung menghasilkan produk yang keras, karena proses mekar hanya terjadi secara terbatas. Pati juga dapat mempertahankan daya awet dengan mempertahankan tekstur garing selama penyimpanan.

Pada perlakuan C (40\% air yang ditambahkan) jumlah kadar pati terendah karena, pada perlakuan $\mathrm{C}$ molekul pati tidak memiliki jumlah gugus hidroksil yang sangat besar sehingga kemampuan menyerap air tidak besar. Selanjutnya pengembangan granula pati juga disebabkan masuknya air ke dalam granula dan terperangkap pada susunan molekul-molekul penyusun pati. Mekanisme pengembangan tersebut disebabkan karena molekul-molekul amilosa dan amilopektin secara fisik hanya dipertahankan oleh adanya ikatan hidrogen lemah. Atom hidrogen dari gugus hidroksil akan tertarik pada muatan negatif atom oksigen dari gugus hidroksil yang lain. Bila suhu suspensi naik, maka ikatan hidrogen makin lemah, sedangkan energi kinetik molekul-molekul air meningkat, memperlemah ikatan hidrogen antar molekul air.

Menurut Radley (1976), fungsionalitas pati pada produk pangan ataupun non pangan tergantung dari sifat fisik pati. Sifat fisik pati tersebut dipengaruhi oleh dua komponen utama dalam pati yaitu amilosa dan amilopektin. Menurut Matz (1992), tingkat pengembangan dan tekstur dari makanan ringan (snack) dipengaruhi oleh rasio dari amilosa dan amilopektin. Menurut Balagopalan et al. (1988), tekstur pada produk berbahan dasar pati diperoleh dari hasil perubahan pati selama dan setelah pemasakan. Beberapa faktor yang mempengaruhi tekstur produk antara lain gelatinisasi, daya kembang, viskositas, dan retrogradasi. Faktor pH pada pati juga dapat mempengaruhi mutu produk berbahan dasar pati. Menurut Taggart (2004), asam dapat mengganggu ikatan hidrogen yang terdapat dalam pati, sehingga menyebabkan granula pati lebih mudah untuk mengembang. 


\section{KESIMPULAN DAN SARAN}

\section{Kesimpulan}

Dari penelitian studi penambahan air adonan terhadap karakteristik stik pangsit, dapat disimpulkan :

1. Studi penambahan air adonan terhadap karakteristik stik pangsit memberikan pengaruh nyata menurut uji lanjut BNJ pada taraf nyata $5 \%$ terhadap kadar air, kadar pati dan uji organoleptik terhadap nilai warna.

2. Dari hasil penelitian yang telah dilakukan pada studi penambahan air adonan terhadap karakteristik stik pangsit, perlakuan terbaik terdapat pada perlakuan A yaitu (30\% air yang ditambahkan) dengan Kadar air dengan nilai 1.2761, Kadar pati 48.708, dan uji organoleptik dengan warna 4.2500, aroma 3.7500 , rasa 3.6500 dan tekstur 4.0500 .

\section{Saran}

Untuk penelitian selanjutnya diharapkan dapat melakukan penelitian lain dengan memperhatikan faktor selain penambahan air adonan seperti suhu penggorengan atau lama pengadukan serta meneliti berapa lama daya simpan stik pangsit.

\section{DAFTAR PUSTAKA}

Ali Khomsan. 2003. Pangan dan Gizi untuk Kesehatan. Jakarta: PT.Rajagrafindo Persada.

Assosiation Of Official Analytical Chemist, 2005. Official Method Of Analysis of The Assosiation Of Official Analytical Chemist. Arlington : The Assosiation Of Official Analytical Chemist, inc.
Astawan, Made. 1999. Membuat Mie Dan Bihun. Penebar Swadaya. Jakarta.

Astawan, M. 2006. Membuat Mie Dan Bihun. Penebar Swadaya. Jakarta.

Balagopalan, C., Padmaja, G., Nanda, S.K., dan Moorthy, S.N. 1988. Cassava in

Badan Standardisasi Nasional. (2000). Makanan Ringan Ekstrudat. Jakarta.

Booth RG. 1990. Snack Food. New York: Van Nostrand reinhold Food, Feed, and Industry. CRC Press, Baco Raton, Florida

Hanafiah, K.A. 2005.Rancangan Percobaan. Jakarta : PT Raja Grafindo Persada.

Kartika, B., P. Hastuti dan W. Supartono, 1988. Pedoman Uji Inderawi Bahan Pangan. Pusat Antar Universitas Pangan dan Gizi. Universitas Gadjah Mada, Yogyakarta.

Marlyna, S. 2006. Mempelajari pengaruh kadar air terhadap karakteristik mutu dan minimalisasi waste selama proses produksi snacktaro net Di Pt. Rasa Mutu Utama, Bogor

Matz SA.1997. Snack Food Technology. $3^{\text {rd }} \quad$ edition. Pan-Tech International Inc., Texas

Matz.1992. Bakry Technology and Enginnering. Van Vostrand Reinhold. New York.

Marahimin.2001.Buletin Penelitian Dan Pengembangan Teknologi Pertanian.vol 3;no 12 Desember 1981.Pusbangtepa-RTDC.IPB Bandung.

Mudjajanti, E.S.L.N. Yulianti, 2004. Membuat Aneka Roti. Jakarta : Penebar Swadaya.

Pongsawatmanit, R., P. Thanasukarn dan S. Ikeda. 2002. Effect of sucrose 
on RVA viscosity parameters, water activityand freezable water fraction of cassave starch suspensions. Science Asia 28 : 129-134

Putri, Ayu Dewiani Yuharnanda, 2011. Makanan Ringan Ekstrudat. http://yuharnandhaputri.blogspot. com. Diakses 25 Mei 2013.

Radley, J.A. 1976. Starch Production Technology. Applied Science Publishers, London.

Rampengan, V.J. Pontoh dan D.T. Sembel., 1985.Dasar-Dasar Pengawasan Mutu Pangan.Badan Kerjasama Perguruan Tinggi Negeri Indonesia Bagian Timur, Ujung Pandang.

Rubianty dan Berty Kaseger, 1985. Kimia Pangan. Badan Kerja Sama Perguruan Tinggi Negeri Indonesia Bagian Timur, Ujung Pandang.

Sapta, Dinata Abi, 2011. Air. http://abipbu6.blogspot.com/2011 /05/air.html. diakses pada tanggal 1 juni 2013.

Safitri. 2003. Studi Pembuatan Fruit Leather Mangga-Rosella.

Program Studi Ilmu Dan Teknologi Pangan Jurusan Teknologi Pertanian Universitas Hasanuddin. Makasar.

Slamet, Sudarmadji, dkk. 2003. Analisa Bahan Makanan dan Pertanian.Kanisius. Yogyakarta.

Soekarto. 1985. Penilaian Organoleptik untuk Pangan dan Hasil Pertanian. Bahtara Karya Aksara. Jakarta.

Soenaryo, E. 1985. Pengolahan Produk Serealia dan Biji-Bijian. Bogor : Jurusan Teknologi Pangandan Gizi. Institute Pertanian Bogor.

Suprapti, Lies, Ir. M. 2005. Tepung Tapioka. Kanisius. Yogyakarta.
Suprapto. 2004. Pengaruh Lama Blanching Terhadap Kualitas Stik Ubijalar (Ipoema Batatasl.) Dari Tiga Varietas. Prosiding Temu Teknis Nasional Tenaga Fungsional Pertanian. Malang

Sudarmadji, Slamet, Bambang Haryono dan Suhardi, 1997. Prosedur Analisa Untuk Bahan Makanan dan Pertanian. Liberty.Yogyakarta.

Sudarmadji,S., dkk. 2003. Analisa Bahan Makanan dan Pertanian.Kanisius.Yogyakarta.

Sulaeman A. 2003. Snack Food Industry (modul 10). Kerjasama Pusat Studi Pangan dan Gizi IPB dan PT Sucofindo.

Sultanry dan Berty Kaseger, 2005. Kimia Pangan. Badan Kerjasama Perguruan Tinggi Negri Indonesia Bagian Timur

Taggart, P. 2004. Starch as an ingredients : manufacture and applications. Didalam: Ann Charlotte Eliasson (ed). Starch in Food: Structure, Function, and Application. CRC Press, Baco Raton, Florida.

Tian S.J., J.E. Rickard and J.M.V. Blanshard. 1991. Physicochemical properties of sweetpotato starch. J. of the Science of Food and Agriculture 57: 459-491.

Winarno, F.G., 2002. Kimia Pangan dan Gizi. Gramedia, Jakarta.

Winarno, F.G., 2004. Kimia Pangan dan Gizi. Gramedia, Jakarta.

Widyaningsih, T.B.E.S. Murtini 2006. Alternatif Pengganti Formalin Pada Produk Pangan. Trubus Agrisarana, Surabaya.

Zuhry, Ahmad, Mahmudan. Iordbroken. 2010. Proses Pembuatan Mie. 11 April 2012. 